\title{
TROPHIC ULCERS IN THE CARPAL TUNNEL SYNDROME
}

\author{
ABELARDO Q.-C. ARAUJJ *, HENRIQUE BARROS NETO **, HENRIQUE BULCAO **, \\ OSVALDO J. M. NASCIMENTO *
}

\begin{abstract}
SUMMARY - A patient with carpal tunnel syndrome (CTS) and trophic ulcers is described. Despite the healing of the ulcers after surgery for CTS, the severe sensory deficit and the eiectrophysiological tests have not shown any significant improvement. We think these findings argue against the hypothesis of the sensory deficit being responsible for the trophic uicers. We favor a major role for the sympathetic disturbances as the main cause for those lesions.
\end{abstract}

KEY WORDS: median nerve, carplal tunnel syndrome, autonomic dysfunction

\begin{abstract}
Mal perfurante valmar e síndrome do túnel do carpo.
RESUMO - Relata-se o caso de paciente com síndrome do túnel do carpo (STC) de longa evolução que exibia mal perfurante palmar. Submetida a cirurgia descompressiva (epineurólise microcirúrgica do nervo mediano e tendossinovectomia) houve rápido desaparecimento das lesões cutâneas embora o déficit sensitivo e as alterações aos testes neurofistológicos não revelassem melhora significativa. Acreditamos que estes achados falem contra a hipótese de que as graves alterações tróficas ocasionalmente encontradas nestes enfermos sejam consequentes ao severo deficit sensitivo. Tais anormalidades devem ser devidas à disfunção das fibras simpáticas do nervo mediano.
\end{abstract}

PALAVRAS-CHAVE: nervo mediano, síndrome do túnel do carpo, disfunção antônoma.

Although carpal tunnel syndrome (CTS) is the most common cause of entrapment neuropathies 4 severe trophic lesions are a rare complication of it. No case is described in Phalen's series of 654 patients 7 and, surprisingly, only a few patients have been described in the literature 1-3,5,6,8. We present an additional patient with such a finding. After being submitted to a surgical release of her median nerve (MN) at the carpal tunnel (CT) she recovered from her trophic ulcers. In spite of that she maintained a very severe sensory deficit.

\section{CASE REPORT}

LAMG, a 62 year old, right-handed housewife had been developing, since her last pregnancy 28 years before, progressive and bilateral symptoms consistent with CTS. The symptoms were worse in the right hand. She complained also of painless ulcerations on the index and middle fingers of her right hand that arose some months before. Her previous history was unremarkable and she was otherwise well. The neurological examination revealed a classical and bilateral CTS with bilateral thenar atrophy, weakness of the abductor pollicis brevis (APB), Tinel and Phalen signs. There was a severe lass of all sensory modalities in the volar aspect of the thumb, index and middle fingers. On the tip of the volar surface of the right index and middle fingers and on the lateral face of the proximal phalanx of the index finger there were multiple, painless, ulcerated lesions, without any sign of inflammation.

* Department of Internal Medicine (Neurology), Universidade Federal Fluminense, Niteroi; ** Hand Surgery Unit, Santa Casa de Misericordia, Rio de Janeiro.

Dr. Abelardo de Queiroz-Campos Araújo - Rua Gildásio Amado 55/1011 - 22631-020 Rio de Janeiro RJ - Brasil. 
The skin over these phalanxes was glossy and reddish and the middle finger had a swollen aspect (Fig. 1). The clinical examination was unremarkable as well as the routine laboratory investigations and the $\mathrm{X}$-ray of both hands. The nerve conduction studies showed a complete conduction block of the MN at the level of the wrist, with absence of both sensory action potentials and compound muscle action potentials in the right hand. In the left hand there were absent sensory action potentials, a marked decrement in the amplitude of the muscle action potentials and a prolonged distal motor latency of the APB. The nerve conduction studies of the MN above the wrist were normal, as well as the electrical studies of the ulnar and radial nerves. The electromyography (EMG) showed signs of denervation in both APB, malnly in the right hand. The patlent underwent a surgtcal CT release with flexor tenosynovectomy and microepineurolysis of the $M N$ in the right hand. Three months after the surgery there was a complete healing of the gkin lesions (FIg. 2) as well as the painful disestheslas and the Tinel sign. However, the sensory loss remained unchanged. The repetition of the electrophysiological tests, three and six months after the surgery did not show any significant improvement in the measurements.
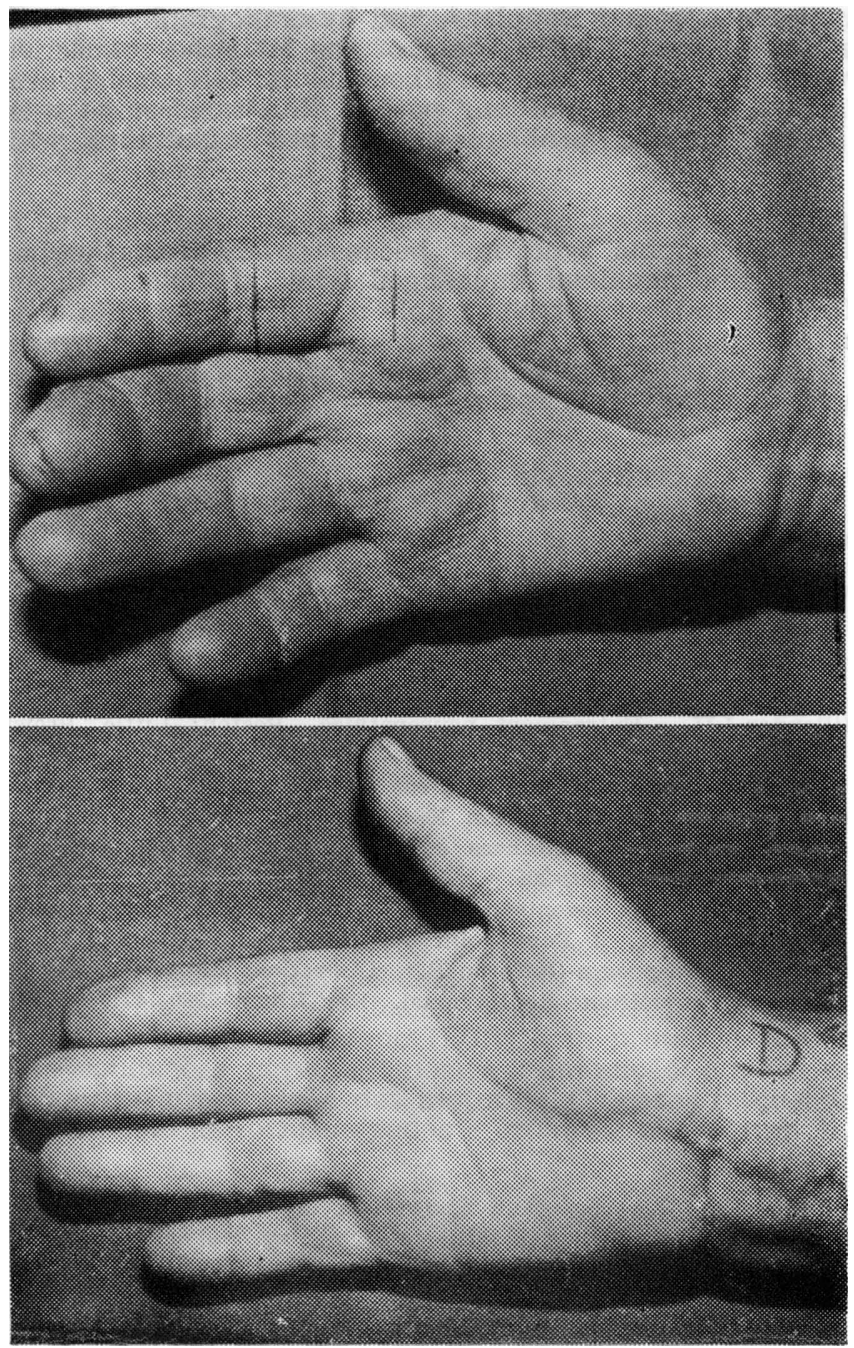

Fig. 1 (above). Severe trophic ulcerations in the right hand. Before operation.

Fig. 2 (below). Compiete healing of the trophic leslons three months after microepineurolysis of the MN and tenosynovectomy. 


\section{COMMOENTS}

The ulcerating forms of CTS 1,3,5,6 usually occur in older patients than the non-ulcerating forms. They tend to happen mainly in people engaged in heavy and manual works and the symptoms evolve for many years (Mean: 9 years). They are associated with severe sensory deficits, muscular weakness and atrophy, trophic dysfunctions (such as dyskeratosis, skin dryness, skin atrophy) and vasomotor disturbances (Raynaud phenomenon 8 ). In some patients they are related with osteolysis of the phalanxes and, in more severe cases, with spontaneous amputation of the distal phalanx of the fingers. The lesion is found mainly in the volar or in the subungueal region of the distal phalanx of the index or third finger 1,3,5,6. The nerve conduction studies and the FMG usually show a severe conduction block with signs of denervation in the MN territory 1,3,5,6. The surgical results are frequently very effective in promoting the healing of the lesion 3 although in some patient the ulcers may recur 5 .

A summation of factors is supposed to be involved in the pathogenesis of the problem. The association with severe sensory loss would predispose the patient to multiple local micro-trauma; the existence of vasomotor disturbances, confirmed by hypoperfusion in the digital circulation of these hands, as evidenced by thermography 3 , capillaroscopy and Doppler 1 , and by angiography 2 , would suggest an important role for the sympathetic fibers of the MN; the connection with older ages where a rarefaction of the nervous fibers of the MN occurs, also could be a predisposing factor ${ }^{5}$. The case of our patient illustrates some interesting aspects of the severe trophic problems sometimes associated with the CTS.

We think that our patient is a good example that the anesthesia per se is not a good explanation for the trophic syndrome because even after she has been operated the sensory deficits remained unchanged while the ulcers disap. peared completely. Therefore, in spite of not being able to perform specific tests for autonomic function in this patient, we favor a major role for the sympathetic disturbances as the main cause for this rare complication of CTS. Further studies are needed, however, to clarify this issue.

\section{REFERENCES}

1. Adoue D, Arlent Ph, Gireud P. Syndrome du canal carpien avec ulcerations digitales chez un insuffisant renal en hemodialyse periodique, Ann Dermatol Venereol 1984, 111:1019-1021.

2. Amschler A, Hartmann A. Ungewohnlicher Fall von Karpaltunnel Syndrom. Hautarzt 1979, 30:398-399.

3. Bouvier M, Lejeune $E_{\text {, }}$ Roullat $\mathbf{M}$, Marionnet J. Les formes ulcero-mutilantes du syndrome du canal carpien. Rev Rhum 1979, 46:169-176.

4. Dawson DM, Hallett M, Millender LH. Entrapment neuropathies. Boston: Little, Brown \& Co, 1983, p 5-59.

5. Geffray L, Leman Ch, Dehais J, David-Chausse J. Deux cas de syndrome du canal carpien avec ulcerations digitales et acro-osteolyse. Rev Rhum 1984, 51:45-47.

6. Neau JPh, Gil R, Boissonnot L. Ulcerations cutanees et arteolyse dans le syndrome du canal carpien. Rev Neurol (Paris) 1987, 143:303-305.

7. Phalen GS. The carpal-tunnel syndrome: seventeen years' experience in diagnosis and treatment of six hundred fifty four hands. J Bone Joint Surg 1966, 48:211-218.

8. Treves R, Arnauld JP, Benabbou M, Desproges-Gotteron $R$. Ulserations digitales au cours d'un syndrome du canal carpien avec syndrome de Raynaud. Rev Rhum 1980, 47:578-579. 